\title{
The Learning Needs Analysis of English for Specific Purposes (ESP) in College*
}

\author{
GUO Hui \\ Qingdao University of Science and Technology, Qingdao, China
}

\begin{abstract}
English for Specific Purposes (ESP), as the bridge curriculum between an ordinary English (EGP) and the English, helps meet the actual needs of students, so it is necessary to introduce ESP into College English teaching. In this paper, based on the needs analysis theory, it studies demand conditions of English for Specific Purposes for non-English majors through questionnaires. The survey finds that the demand for professional learning is growing and the existing English skills cannot reach the demands of their professional teachers. The current college English teaching cannot fully reflect and effectively meet the learning needs of students, so there is the need to strengthen students' English practical application ability and to strengthen the overall intercultural quality of students in English teaching. Based on the analysis results, the article puts forward some suggestions in the hope that the data and analysis provided herein can provide some references for the course construction of College English.
\end{abstract}

Keywords: needs analysis, ESP courses, course construction

\section{Introduction}

The present English teaching condition shows that most of the colleges and universities still adopt the traditional college English teaching mode, namely English for General Purposes (EGP). This kind of teaching mode is beneficial to cultivate the students' language ability, but cannot cultivate the students' practicability and professional ability and the students' practical English ability is poor. The popularization of China's foreign language education promotes the all-round development of science and technology, society and culture, but it is undeniable that the students' English application ability is very weak, though they have received many English certificates. And why the input and output of foreign language education results could be so poor? As professor SU Ding-fang says, the lack of consistency and lack of a throughout evaluation criteria from middle school to university could be the current conditions of China's foreign language teaching. According to the stage development of foreign language teaching, college students should have the basic English knowledge and it is unnecessary to have general English course. In order to help students adapt to the English professional courses, universities can provide ESP courses in academic aspects of English skills or professional aspects according to the requirements of students.

\footnotetext{
* This paper is the research result of Teaching Reform Research Project in Shandong colleges and universities (Project Number: 2015M084)

GUO Hui, lecturer, M.A., English Department, Qingdao University of Science and Technology.
} 
However, the domestic secondary school education is examination-oriented education. Students study the language knowledge system in high school, but they feel very difficult to adapt to the academic and professional English courses in colleges. The most common learning problems of college students are reflected in their lack of solid foundation of general English, lack of learning strategies, and excessive dependence on the teacher.

Needs analysis, as a concept of evaluation research category, has been used and studied in overseas foreign language teaching for more than 30 years. There are different explanations for needs analysis in foreign countries and its aim is to form a decision and to improve teaching. Therefore, needs analysis is a diagnosis of behavior conducted before implementing and improving the teaching plan and it can also provide some certain bases for English teaching material compilation, making teaching material more suitable for the objective requirement of the students and thus improving students' learning interest. Needs analysis bears a great significance for the current English teaching in China and it is gradually attracting attention of inside and outside of the language teaching in China. Needs analysis is the premise of designing the syllabus according to the actual situation of the school. The premise of designing the syllabus is to make the need analysis, and if all aspects of the demand of students in the learning process have been only fully understood, teaching plan suitable for the practical teaching objectives can be made. Needs analysis is an essential step to set ESP courses and also the final goal of the ESP courses.

Based on theory of needs analysis, through the questionnaire survey, this paper studies the demand investigation of non-English major students for ESP in order to understand the need of teachers and students for (ESP) in English. English for Specific Purposes, or ESP pays attention to cultivate students' professional communication skills. According to the result of questionnaires, for the purpose of improving and upgrading the efficiency of non-English major students' public English teaching, the ESP teaching mode needs to be introduced into the university public English teaching and a suitable teaching system should be established for non-English major students. This helps to improve the quality of the public English teaching for non-English majors, realizing the goal of English teaching.

\section{The Theory of ESP and Its Characteristics}

English for special purposes (ESP) refers to a related English with a particular career or discipline and a specific courses in English established according to the specific purpose and the needs for learners. It aims to cultivate students' communication skills to use English for work. It is not a long time since ESP has been introduced into the education of Chinese universities. LIU Run-qing points out that the future English learning is no longer a pure English learning and the future English learning will be more and more banded together with the specialized knowledge or a particular aspect of a subject. English for special purposes will become the mainstream of the English teaching in the 21st century. Compared with the general English (EGP), ESP teaching has its obvious characteristics. From the point of view of the pure teaching: (1) ESP teaching has a clear purpose. ESP learners do not study English merely for purpose of language learning, but to study a particular professional course by means of studying the language; (2) The ESP teaching is based on learners' needs analysis. The choice of teaching content and teaching method takes the students' learning need into account, namely the communication activities which the students could have in their study or work and the knowledge and ability which they need when carrying out the communicative activities; and (3) ESP teaching pays attention to the 
cultivation of students' pragmatic competence. English learners would mainly use English in a particular professional scope in order to achieve the purpose of communication in English and this means that the learner's knowledge of learning and language use can not be separated.

\section{The Necessity and Feasibility Analysis of ESP Teaching}

\section{The Necessity Analysis of ESP Teaching}

ESP teaching is helpful to meet the social demand for professional talents. The general English teaching takes the language knowledge and skills as a general teaching content and involves less professional Terms. EGP cannot fully meet the social requirements of talents' foreign language knowledge. With the continuous development of global economic integration and the strengthening of our foreign economic cooperation, the enterprises demand higher and higher the requirement of employees' foreign language ability, especially their foreign language ability in the professional fields. Through the cultivation of specialized foreign language ability, ESP enables students to master the professional English knowledge and skills, so that the students can quickly absorb the world's advanced scientific and technological achievements and information after they start to work and can apply English to the work, continuously promoting the development of enterprises. For a long-term, our colleges and universities mainly emphasizes the ability to read and the expression ability of written English, the ability of speaking and listening cannot meet the needs. The setup of the professional English course is not perfect and even some universities could not offer professional English and bilingual teaching courses. Thus, society has a great demand for the students with a strong professional English listening, speaking, reading, and writing abilities cultivated by the ESP teaching. ESP teaching helps to improve teaching effect and student's enthusiasm.

Traditional college English teaching mainly uses a unified general books and requires students to pass College English Band-4 and Band-6, focusing less on the English professional applications. Traditional college English teaching also adopts the form of large class teaching and teachers and students are lack of interactivity. ESP takes different teaching contents for different majors according to students' needs and emphasizes on cultivating students' language application ability, helping to improve the teaching effect and student's study enthusiasm. ESP teaching is beneficial to students for their future work. A student with good basic English, who cannot understand professional vocabulary, syntax structure, expression, etc., could not read English professional literature or adapt to their own work immediately after they step into their own professional field. ESP teaching is a kind of practical English teaching based on the requirement of the professional development and through the ESP teaching, students can master the professional English better and carry out their future work better.

\section{The Feasibility Analysis of ESP Teaching}

First of all, ESP is based on a in-depth research and a solid academic foundations and there are many ESP research papers. Taking China Journal Full-text database search as a tool to retrieve the theme item and taking ESP and English as a search term, there are 828 qualified literatures from 2000-2010. Taking ESP as a search term, there are a total of 800 qualified literatures from 2000-2010, among which there contains 359 ESP literatures. It can be seen that many scholars have carried out research on the ESP. As for research content, the existing research literatures studies ESP from multiple perspectives of teaching methods, curriculum development, teacher education, etc., with a in-depth academic research base. 
Second of all, students have a certain English basis and learning skill. The teaching goal of high school English is: to strengthen the students' comprehensive language using ability and to improve students' ability to obtain information, process information, analyze and solve problems. After learning general English learning in university, most students possess good language using ability of listening, speaking, reading, and writing, and this kind of English learning basis and learning skills are necessary for students to learn ESP. Moreover, most schools have the ability to develop good ESP teaching. ESP teaching is based on learners' needs analysis, carrying out around the practical needs of professional communication, so for the different setup of professional courses , a small-class teaching model should be made according to different majors. At present, most schools adopt ESP for class or professional units and satisfy the requirement of ESP teaching. In addition, more and more schools pay attention to the foreign language level of professional teachers, some schools take the experience of being abroad or visiting scholar teachers as one of the essential requirements of professional evaluation. These measures can improve the English level of college teachers, but also can provide rich teaching resources for ESP teaching.

\section{The Research Method}

\section{The Object of Study}

Select second-year, non-English major undergraduate students of Qingdao University of Science and Technology as the research objects. Subjects are the sophomore and they almost finish the basic stage of college English study. 130 questionnaires have been sent and 118 effective questionnaires have been collected.

\section{Research Tools and Data Collection}

This study uses questionnaire survey to investigate students' ESP perception demands for learning and target requirements. Survey questions score by Likert 5 way. The questionnaire included 20 questions, questions 1-5 survey students' English comprehensive application ability assessment; Questions 6-15 survey students' target needs of ESP learning, learning motivation and learning attitude; Questions 16-20 investigate students' view of ESP contents and ESP methods. Statistics are counted and analyzed by using Excel.

\section{Results}

\section{Self-assessment of Students' English Comprehensive Application Ability}

Most students' (77.97\%) self-assessment of their English comprehensive application ability is low. $21.19 \%$ of the students show that after studying the general English, they are able to understand professional English materials by using English dictionary. $29.66 \%$ of the students sometimes could understand and $47.46 \%$ of the students cannot understand professional English materials; only a small number of students (23.73\%) show that they could have professional communication in English. $41.53 \%$ of the students sometimes could and $33.9 \%$ of the students feel very hard to have professional communication in English. According to the students' self-evaluation, after two years of general English learning, students have a low assessment for their professional English comprehensive application capability and they are lack of confidence with low satisfaction. Why students feel difficult lies in that the teaching material content is not professional for the two-year general English teaching and the teaching content focuses on the literature and history, emphasizes enjoyment and plots, but there is a lack of professional emphasis. The undergraduate students are under the control of the pressure of CET band- 4 and band- 6 and they invest less time and effort in learning professional English. 


\section{Learning Goals, Motivation, and Attitude of ESP}

Most of the students $(80.51 \%)$ think they learn ESP only for future career development. This earning motivation belongs to the instrumental motivation, namely they regard English as a tool and they study it just for the purpose of future personal career development. Most of the students (64.41\%) has strong will and interest to learn ESP. First and second grade students only have college general English courses and they have less chance to learn ESP. The second grade students have mastered some basic knowledge of English and public English learning has reached a certain level, so they have a certain understanding of ESP. At this period, they have great desire to learn ESP. $25 \%$ of the students have a little interest and only $10 \%$ of the students are not interested in ESP. Half of the students (51.69\%) think that ESP can help them master more professional knowledge by taking English as a tool. Above shows that most students hold a positive attitude towards the ESP courses. They realize that English as a tool is very important for their career development and this conforms to the pertinence and high practical value characteristics of ESP courses. The research results of students' learning goals show that the vast majority of students (83.9\%) hope to communicate professional information in English through the ESP courses learning. $77.8 \%$ of the students hope that they can read professional English materials through the study of ESP courses and $82.5 \%$ of the students hope to improve listening and speaking skills through the study of ESP courses. This shows that most students expect to improve professional communication ability by learning ESP courses and hope to apply what they have learned though ESP courses to the professional work in the future.

\section{The ESP Teaching Content and Method}

$82.2 \%$ of the students hope to improve listening and speaking skills by ESP courses. $77.12 \%$ of the students hope that through the study of ESP courses they can read English materials and $67.8 \%$ of the students hope to improve the ability of writing and translation through the study of ESP courses. This indicates that the students take much count of listening, reading, writing, and translation skills seriously, especially paying more attention to listening and speaking. As we can see, students set ESP learning goal on the needs to work and emphasize the practicability of learning. A fundamental characteristic of ESP curriculum is that curriculum setting must satisfy the special needs of learners. With the students' interest support, organizing ESP teaching closer to the application in work, education workers will receive twice the teaching effect with half the effort. $78.81 \%$ of the students hope to communicate with teachers and classmates and do some real scene simulation practice, rather than merely listen to the teachers' explanation and text translation in ESP class. This shows that students want to enhance English comprehensive application ability, rather than passively accepting knowledge. $55.93 \%$ of the students hope that English can be the main teaching language in ESP courses. English teachers should strengthen students' general English learning in the first and second grade to lay a foundation for the ESP learning. At the same time, this also puts forward higher request for ESP teachers. For English teachers, they need to have higher English level and at the same time have a certain professional knowledge in order to teach ESP course better.

\section{Conclusion}

This paper first analyzes the necessity and feasibility of ESP teaching and ESP teaching is studied through the form of a questionnaire survey of the student needs for ESP teaching situation. It can be seen through the survey, students have a strong desire for ESP learning, and desire to improve the English communicative ability requirements for future work. In the process of teaching ESP, the plan and adjustment should be made timely in 
order to adapt to the requirements of the professional development. The above findings bring some inspiration on ESP teaching. Teachers should maintain and improve student motivation and interest in learning. In the process of teaching, teachers should apply communicative or task-based teaching model, focusing on students and being guided by the content and appropriately reduce translation and reading teaching in class, also increase listening and speaking teaching in the real context, allowing students to take the initiative to get involved in meaningful learning. In addition, ESP would mean higher demand and more severe challenges for teachers. College English teachers not only should continue to play their advantages in language and teaching, but also should enhance the understanding and mastery of professional knowledge. The specific conclusions and recommendations are as follows:

(1) The school should fully understand the needs of students in English learning and develop a set of teaching mode suitable for ESP as soon as possible through detailed analysis. In addition, the student needs analysis is a long-term work, and after the ESP course, teachers should understand the usage of ESP courses and students' learning experience, providing valuable experience for the future course design.

(2) The main purpose of the students to learn English is to work and get more professional knowledge in the future. When teachers and school administrators design the English curriculum, they should consider to set up more relevant professional English courses related to students' future work and related to their majors. Through the study of English course, students can be provided with the better service in the future work.

(3) To strengthen the construction of the ESP teaching materials. Professional direction of ESP courses are different with interdisciplinary nature, so different majors should choose different professional teaching materials according to their professional needs. ESP teaching material needs to be practical and functional and college should adopt suitable textbooks according to the actual situation of students.

(4) Pay attention to promote teacher faculty. ESP teaching puts forward higher demand on teachers. It not only requires the teacher with solid knowledge of the English language and professional knowledge, also requires the teacher to understand the needs of the students. Teachers should work out teaching outlines and adapt text books according to the needs of students. Therefore, it is important to pay attention to the improvement of teachers, strengthen the training of teachers, and improve teacher's professional level.

\section{References}

Brown, D. (2000). The elements of language curriculum: A systematic approach to program development. New York: Heinle and Heinle Publishers.

Hutchinson, T., \& Waters, A. (1987). English for specific purposes: A learning-centered approach. Cambridge: Cambridge University Press.

Hutchinson, T., \& Waters, A. (2002). English for specific purposes. Shanghai: Shanghai Foreign Language Education Press.

Reid, J. M. (1995). Learning styles in the ESL/EFL classroom. Boston: Heinle \& Heinle Publishers.

Richards, J. C. (1984). Language curriculum development. RE LC Journal, 15(1), 1-29.

Richterich, R. (1972). A model for the definition of languages needs of adults learning a foreign language. Strasbourg: Council of Europe. 